УДК $94(4+73)$ «196...»

DOI: https://doi.org/10.33782/eminak2021.2(34).529

\title{
THE CONDITION OF NATIONAL MINORITIES IN EASTERN EUROPE IN A SECRET CIA REPORT FROM 1965
}

\author{
Arthur Tulus \\ «Dunarea de Jos» University of Galati (Galati, Rumania) \\ e-mail: arthur.tulus@ugal.ro \\ ORCID: https://orcid.org/0000-0002-4368-7231
}

In the context of the Cold War, detailed knowledge of the opponent and espionage were fundamental elements in the security policies of the two antagonistic sides. The CIA, the United States' foreign intelligence service, identified the condition of ethnic minorities as one of the possible vulnerabilities of the Eastern Camp, judging from the perspective of the restrictive policies that Communist states held regarding rights and freedoms. Our study is based on the analysis of a document prepared by the CIA in 1965, a memorandum that took data from the latest official censuses in Bulgaria, Romania, Yugoslavia, Albania, Czechoslovakia, Hungary, and Poland, and recorded the effects of assimilation policies on national minorities within the Eastern Communist states. The document is all the more interesting as the issue of national minorities rights' in the Communist world was taboo.

Keywords: Eastern Europe, the Cold War, Communist regimes, demographic statistics, the minorities issue

Our study relies on a document elaborated by the Central Intelligence Agency (CIA in short), the United States of America's foreign information service ${ }^{1}$. Among other things, the CIA's role was to collect foreign data, which was later used by its experts in elaborating ample briefings to be made available to American and North Atlantic Pact (NATO) decision-makers. The document ${ }^{2}$ that we have analyzed was circulated by the CIA in July 1965 and focuses on the situation of national minorities in Eastern Europe, an area held under Soviet influence until 1989.

A direct opponent of the $\mathrm{KGB}^{3}$ and in the midst of the Cold War with the Communist Bloc, the CIA was concerned with identifying the vulnerabilities of the adversary, the issue of minorities being one of them. Less than a year before the document was drafted, during the plenary session of the CPSU's Central Committee on October 14th 1964, Nikita Khrushchev was removed from power and replaced by Leonid Brezhnev as First Secretary. Khrushchev's regime, which after the death of I.V. Stalin (March 1953) was supposed to be a turning point in Soviet politics marked by internal and external thawing, had ultimately proved controversial, generating numerous crises (we mark only the most important ones - the Hungarian revolution of 1956, the erection of the Berlin Wall in 1961, the Cuban Missile Crisis of 1962). At the same time, especially for its medium and long-term effects, Khrushchev's regime had cracked the monolithic unity of the Communist Bloc, which in Stalin's time had been based on unconditional

\footnotetext{
${ }^{1}$ For further information concerning CIA activity see: https://www.cia.gov

2 Release Of Cia/Bi Gm 65-4, National Minorities In Eastern Europe, July 1965, Fouo, To Foreign Governments // https://www.cia.gov/readingroom/docs/CIA-RDP84-00825R000100120001-2.pdf

3 KGB (short for «Комите́т Госуда́рственной Безопа́сности»; in English «The Committee for State Security») was the Soviet Union's main foreign information office.
} 
submission and the obedience of the satellite states to the «supreme father». From the 60 's and 70's of the last century we move to the «time of a thousand and one Communisms», taking in the statement of Jean-François Soulet, a renowned and well-known historian of international Communism ${ }^{4}$. Specifically, almost every Communist leader now asserted his own path in the building of Communism, and in most cases these paths lead to the rediscovery and reaffirmation of nationalism.

CIA's briefing saw this exact change in relation to Eastern Europe's issue on minorities. The Soviet hegemony extended over Eastern Europe in Stalin's time had shadowed many deep rooted antagonisms, which had for long existed between the numerous ethnic groups of the region. The gradual weakening of Soviet control over Eastern Europe after Stalin's death favoured the availability of its Communist regimes in promoting policies which served national interests rather than those of the Bloc, a fact that had determined the re-emergence of past national antagonisms.

CIA's briefing analyzes the demographic situation of 7 Eastern European Communist republics - Poland, Czechoslovakia, Hungary, Romania, Bulgaria, Yugoslavia, and Albania - all accompanied by statistics. Although in all of these countries there had been demographic movements generated by border shifts and/or population exchanges during and immediately after the second world war, in addition to the loss of human life during wartime, which had reduced the scale and significance of national minorities, such ethnic groups could still be found in compact areas, which were viewed by Communist authorities as potential threaths to the unity of their own countries, and by the CIA as vulnerabilities within the Communist Bloc.

Another important aspect is the realism of the demographical analysis made by the American experts. They found and noted that neither official censuses or other statistical data, nor secondary, historiographic literature that came from Eastern Europe gave correct information. Census data was falsified and deliberately distorted, hence the secondary literature, by the Communist authorities in order to reduce the real size of minority populations and, in some cases, to completely ignore the existence of a certain nationality found undesirable by the state, by artifices made to various categories included in demographic statistics.

Of the 7 Communist states that are analyzed, Poland, Hungary, and Albania benefited from a higher degree of homogeneity, followed by Bulgaria and Romania. A separate section must be assigned to Czechoslovakia and Yugoslavia. Ever since 1965 American experts noticed the destructive potential of the relationship between a dominant nationality and other, smaller or weaker group(s). In the case of all the states analyzed in the document, I preferred to intervene as little as possible on the text in order to preserve the accuracy of the information and the point of view of the American experts.

\section{POLAND}

The size of the minority population of Poland is not accurately known, but it is only a fraction of that recorded before the war. Poland may now have a higher degree of ethnic homogeneity than any other country under discussion. According to current reports the minority population is between 1.5 and 5.5 percent of the total population of Poland, de-

\footnotetext{
${ }^{4}$ For further details on Khrushchev's regime see: Soulet Jean-François. Istoria comparată a statelor comuniste din 1945 până în zilele noastre. Polirom, București, 1998. P. 87-142. The author suggestively named chapter VI Perioada celor o mie şi unul de comunisme [The time of a thousand and one Communisms].
} 
pending on the source of information and the criteria used in defining minorities by nationality. In absolute figures this would be between 0.5 million and 1.7 million people, most of whom live in the German areas placed under Polish administration after World War II. In contrast, the prewar minority population numbered approximately 10 million, or about 32 percent of the total population.

\begin{tabular}{|l|l|l|}
\hline \multicolumn{3}{|c|}{$\begin{array}{c}\text { Population of Poland, by Nationality } \\
\text { (Estimate, 1961-62) }\end{array}$} \\
\hline \multicolumn{1}{|c|}{ Thousand } & \multicolumn{1}{c|}{ Percent of total } \\
\hline Poles & 29,680 & 98.5 \\
\hline Minorities & 453 & 1.5 \\
\hline Ukrainians & 180 & 0.6 \\
\hline Belorussians & 165 & 0.5 \\
\hline Jews & 31 & 0.1 \\
\hline Slovaks & 21 & negl \\
\hline Great Russians & 19 & negl \\
\hline Gypsies & 12 & negl \\
\hline Lithuanians & 10 & negl \\
\hline Greeks & 5 & negl \\
\hline Macedonians & 5 & negl \\
\hline Germans & 3 & negl \\
\hline Czechs & 2 & negl \\
\hline Total & $\mathbf{3 0 , 1 3 3}$ & $\mathbf{1 0 0 . 0}$ \\
\hline
\end{tabular}

The latest (1961-62) estimates from Polish sources indicate a total minority population of only about 450,000. Eleven distinct minority groups are included, but only two Ukrainians and Belorussians - are credited with more than 100,000 members. With the exception of the figure for the German minority, these estimates are probably fairly accurate.

Germans: The 1961-62 Polish estimate of only 3,000 for the German minority is undoubtedly a gross understatement of its true size. Conversely, German estimates of as much as 1.2 million are doubtless greatly exaggerated. This discrepancy between Polish and German estimates reflects fundamental differences in the criteria used in the identification of Germans and Poles, particularly as this relates to people of mixed blood. The transfer of the German lands east of the Oder-Neisse to Poland after World War II resulted in the mass expulsion of the resident German population and its replacement mainly by Polish settlers from other areas. At the time of the Polish occupation of the Oder-Neisse territories, however, the Polish authorities reclassified some 1.3 million inhabitants as Autochthonous Poles who were thereby exempt from being transferred to Germany. This group consists mainly of bilingual people of Polish-German ancestry, although it probably also includes a number of Germans proper who at the time assumed the identity of Autochthonous Poles, or Autochthons, in order to avoid expulsion. In data from German sources these people still are regarded as Germans. Some 300,000 or more Germans and/or Autochthons are believed to have left Poland since about 1955, mostly in a fairly regular flow of repatriates from Poland to East Germany and even more to West Germany. The number of Germans and persons of mixed Polish-German ancestry in Poland now is probably about 1 million. 
Ukrainians and Belorussians: The 180,000 Ukrainians in Poland form, by Polish estimates, the largest minority now resident in the country. Before the war most of the Ukrainians within the present Polish boundaries lived in Rzeszow Province, but in 1947 many were forcibly resettled in other parts of Poland. Today, Ukrainians live in 11 provinces but are concentrated chiefly in those areas gained from Germany after World War II. Olsztyn and Koszalin Provinces have the largest number. In these two provinces the Ukrainians account for 5 to 7 percent of the population, and in some districts the proportion increases to about 25 percent. The Ukrainian minority still in Rzeszow Province accounts for only 1 or 2 percent of the population. In contrast to the widely distributed Ukrainians, a few Belorussians are in Olsztyn Province and the rest of the 165,000 form a compact group in Bialystok Province.

Other Minorities: The Jews, who number only a small fraction of their prewar population, are settled in cities throughout the country. More than one-third are concentrated in the provinces of Wroclaw and Katowice. The smaller minority groups are located chiefly along the margins of the country: Slovaks in southern Krakow Province, Lithuanians in northeastern Bialystok Province, and Great Russians in Bialystok and Olsztyn Provinces. The Gypsies, most of whom still do not have fixed homes, are mainly in the southern provinces. Most of the Greeks and Macedonians are in the Oder-Neisse lands, and the small Czech minority is settled mainly in two small areas along the border with Czechoslovakia. The migration of Germans to Germany has been counterbalanced by the repatriation of Poles from the USSR, reportedly some 300,000 in the period 1957-59. Many of these «repatriates», however, were in fact non-Polish Jews who in turn left Poland for Israel. A new nationality agreement between Poland and the USSR was concluded on 31 March 1965, and this could lead eventually to the repatriation of another 1.4 million people claiming Polish nationality5.

THE CZECHOSLOVAK NATIONALITIES

\begin{tabular}{|c|l|l|}
\hline \multicolumn{2}{|c|}{$\begin{array}{c}\text { Population of Czechoslovakia, by Nationality } \\
\text { Thousand }\end{array}$} \\
\hline Czechs & \multicolumn{1}{|c|}{ Percent of total } \\
\hline Slovaks & 9,069 & 66.0 \\
\hline Minorities & 3,836 & 27.9 \\
\hline Hungarians & 840 & 6.1 \\
\hline Germans & 534 & 3.9 \\
\hline Poles & 140 & 1.0 \\
\hline Ukrainians/Great Russians & 68 & 0.5 \\
\hline Others Total & 55 & 0.4 \\
\hline Thers & 0.3 \\
\hline
\end{tabular}

The nationality problem of Czechoslovakia has special aspects because the country is a binational state of Czechs and Slovaks. Before World War II these two groups accounted

\footnotetext{
5 Excerpt from National Minorities in Eastern Europe, in https://archive.org/details/CIA-RDP8400825R000100120001-2. For a broader picture of Poland's history and politics see: Bogdan Henry. De Varsovie à Sofia. Histoire des pays de l'Est. Paris, 1982; Beauvois Daniel. Histoire de la Pologne. Hatier: Paris, 1995; Tymowski Michal. Une histoire de la Pologne (Essais et documents). Noir sur blanc: Paris, 1993.
} 
for only a little more than 60 percent of the total population, but today they comprise more than 90 percent. The ratio between the Czechs and Slovaks also has altered over the past several decades. The Czechs are the dominant group numerically and economically, but the more prolific Slovaks are increasing at a more rapid rate. In 1921 the Slovaks accounted for less than 23 percent of the combined Czech-Slovak population, whereas by 1961 the proportion had increased to nearly 30 percent. The relatively younger Slovak group is expected to continue to gain at the expense of the Czech group, and to account for as much as 35 percent of the combined Czech-Slovak population by the end of the century.

Both Czech and Slovak populations are concentrated largely within the limits of their respective territories. The Czechs, in particular, have continued to live in the historic Czech provinces of Bohemia and Moravia; only 0.5 percent of the Czech population lived in the Slovak lands at the time of the 1961 census. The Slovaks tend to be somewhat more widely dispersed. In 1961 nearly 276,000 Slovaks, over 7 percent of the entire Slovak population, lived in the Czech lands, mainly in the border territories that formerly were occupied by Sudeten Germans but also in central Bohemia and northeastern Moravia.

Slovakia has a higher proportion of minority peoples than have the Czech lands. The 1961 census lists a minority population of 568,109 in Slovakia, nearly 14 percent of the entire population, and this figure does not include the large Gypsy population. The comparative proportion of minorities in the Czech lands is only about 3 percent.

National Minorities. When Czechoslovakia was established after World War I the ethnic minority population in the new country totaled more than 5 million, or fully one-third of the entire population. The Germans and Hungarians comprised the largest of the national minority groups and, along with the much smaller Polish group, provided the basis for foreign claims on Czechoslovak territory in the late 1930's. Since World War II, the situation has changed substantially as the result of transfers of population and territory. Nearly all of the prewar minority groups have decreased in size, and most of them probably will continue to do so.

Hungarians: The Hungarians now comprise the largest minority in Czechoslovakia. There is some doubt as to its actual size, because postwar Czech reporting has been inconsistent and has tended to minimize the number of Hungarians. The 1961 census figure of 534,000, which is substantially higher than earlier postwar Czech figures, probably is the most accurate count from a Czech source, but even this total may be a considerable understatement. After the war a few Hungarians were resettled in former German areas in Bohemia and Moravia, but most of the Hungarian minority is still located in Slovakia, where it comprises over 12 percent of the population. The main areas of Hungarian settlement are along the border with Hungary, where many villages and a few entire districts are still predominantly Hungarian despite attempts to introduce Slovak settlers.

Germans: The Germans now constitute a relatively unimportant element in the population of the country.

As in prewar times they are located chiefly in the border areas of Bohemia and Moravia. The greatest proportion, over 70 percent, of the German population is concentrated in two districts immediately adjacent to the Bohemian borders with East Germany and West Germany, but Germans in all areas are far outnumbered by Czech inhabitants.

The census of 1961 recorded only 140,000 Germans, indicating a sizable drop from the 165,000 given in the 1950 census. This continuing attrition arises from a small-scale but steady emigration to West Germany, the assimilation of Germans into the dominant 
Czech population, and finally, the comparatively older age level of the German population and correspondingly low rate of natural increase. At present over 25 percent of the ethnic Germans are more than 60 years old, as compared with some 14 percent of the total population in that age group. The future of the German minority seems to be one of continued decline that may lead eventually to its virtual elimination as a significant element in the population.

Poles: The present Polish minority is only two-thirds the size of the prewar group, and it probably will continue to decline in the coming decades. The 1961 census recorded a decrease of nearly 7 percent from the number recorded in 1950 . This loss probably is due partly to the assimilation of Poles into the dominant Czech population but may have stemmed even more from the comparatively older age level of the Polish minority. In 1961 over 16 percent of the Poles were more than 60 years old, a percentage second only to that of the German population. More than 87 percent of the Poles are concentrated in the industrialized north near Cesky Tesin (historic Teschen Province), an area long held in dispute between Poland and Czechoslovakia.

Ukrainians: The transfer of the province of Ruthenia to the USSR after World War II eliminated nearly 90 percent of the large prewar Ukrainian (Ruthenian) population in Czechoslovakia. The remaining Ukrainian group, concentrated mainly in eastern Slovakia, apparently has continued to decrease during the postwar period. The 1961 census lists 55,000 Ukrainians and Great Russians, a drop of nearly 20 percent from the 1950 total.

Gypsies: The Czechoslovak government does not recognize the Gypsies as a distinct nationality, and they are not included in postwar census material. Estimates of the size of the Gypsy minority, however, have appeared in various Czech publications. They range from 120,000 to about 200,000, but the most commonly used figure seems to be 150,000 . On the basis of various postwar estimates, the greatest proportion (80 percent) of the Gypsy population appears to be concentrated in Slovakia, chiefly in the central and eastern sections. Some attempt was made after the war to resettle Gypsies in the depopulated border areas of Bohemia, and it is likely that many, if not most, of the Gypsies now living in the Czech lands are in these sections. As the Gypsies generally have succeeded in resisting assimilation into the Czechoslovak society and economy, they form a relatively troublesome, though apolitical, minority.

Jews: Although not identified in either the 1950 or 1961 census returns, an estimated 20,000 Jews remain in Czechoslovakia. Most of this small group has been assimilated into the dominant Czechoslovak society and a continuation of this process together with some small-scale emigration to Israel will undoubtedly make it increasingly difficult to identify a distinct Jewish group ${ }^{6}$.

\section{HUNGARY}

Postwar data on the size and distribution of national minorities in Hungary are incomplete and often misleading or contradictory. Most data, moreover, are concerned chiefly with the absolute size of minority groups and are entirely inadequate for showing distribution in any great detail. Before World War II, Hungary had the smallest proportion of minority population of any country in Eastern Europe, with the pos-

\footnotetext{
${ }^{6}$ Excerpt from National Minorities in Eastern Europe. For a broader picture of Czechoslovakia's history and politics see: Dubcek Alexandre. C'est l'espoir qui meurt en dernier. Fayard, 1993; Havel Václav. Essais politiques. Points / Calman-Levy, 1989-1990; Lipták Lubomír. Petite histoire de la Slovaquie. Institut d'études slaves, 1996; Marès Antoine. Histoire des Pays techèques et slovaque. Hatier: Paris, 1994.
} 
sible exception of Albania. The 1949 and 1960 censuses show an even greater ethnic homogeneity than in prewar times, with Hungarians accounting for over 98 percent of the population. This reflects the actual physical elimination of most of the Jews and the emigration of more than one-half of the Germans, but it also reflects in part the weaknesses of postwar census data. The 1949 census lists only 129,000 people reporting a non-Hungarian mother tongue, a figure that increased to about 175,000 by the time the 1960 census was taken. It is generally believed that the actual minority population in both instances was much larger. Estimates based not exclusively on mother tongue range from a low of about 450,000 to a high of nearly 750,000 , or 4 to 8 percent of the total population. On the basis of all the available evidence, Hungary's minority population today probably runs to at least 600,000 and may actually be 700,000 , or between 6 and 7 percent of the total population.

The proportion of non-Hungarians varies greatly from one section of the country to another, although in none of the present counties would it be likely to exceed 20 percent. In the main, only the central and western parts of Hungary have significant (over 2 percent) minority populations; only one county in eastern Hungary has an appreciable number of non-Hungarians. An estimated 350 towns and villages have significantly large minority groups (20 percent or more); and only 79 of these settlements actually have a non-Hungarian majority.

\begin{tabular}{|c|l|l|l|l|}
\hline \multicolumn{5}{|c|}{$\begin{array}{c}\text { Population of Hungary, by Nationality } \\
\text { (Estimate, about 1960) }\end{array}$} \\
\hline & Low Estimate for Minorities & High Estimate for Minorities \\
\cline { 2 - 5 } & Thousand & $\begin{array}{c}\text { Percent of } \\
\text { total }\end{array}$ & Thousand & $\begin{array}{c}\text { Percent of } \\
\text { total }\end{array}$ \\
\hline Hungarians & 9,521 & 95.6 & 9,221 & 92.6 \\
\hline Minorities & 440 & 4.4 & 740 & 7.4 \\
\hline Germans & 200 & 2.0 & 220 & 2.2 \\
\hline Gypsies & 50 & 0.5 & 200 & 2.0 \\
\hline Slovaks & 60 & 0.6 & 110 & 1.1 \\
\hline Yugoslavs & 45 & 0.5 & 105 & 1.0 \\
\hline Jews & 70 & 0.7 & 80 & 0.8 \\
\hline Rumanians & 15 & 0.1 & 25 & 0.3 \\
\hline Total & $\mathbf{9 , 9 6 1}$ & $\mathbf{1 0 0 . 0}$ & $\mathbf{9 , 9 6 1}$ & $\mathbf{1 0 0 . 0}$ \\
\hline
\end{tabular}

Germans: The Germans still constitute the largest national minority in Hungary. Estimates of the number of Germans range from 200,000 to about 220,000 and far exceed the number reported in either of the two postwar censuses - 22,000 in 1949 and 51,000 in 1960. Although their precise distribution is not known, the Germans are found now, as in prewar times, mainly in Transdanubia, particularly in the south. Other smaller concentrations are west of Budapest, in the north, and along the Austrian border.

Gypsies: The Gypsy population of nearly 200,000 that has been reported in recent years contrasts sharply with the small numbers - 20,000 to 25,000 - listed in prewar and postwar censuses according to mother tongue. The Gypsies are much more widely distributed than any of the other minorities. They are scattered throughout the country in some 2,100 settlements.

Other Minorities: The Slovaks, estimated to number between 60,000 and 110,000, are 
located chiefly in southeastern Hungary, though smaller settlements are found scattered across northern Hungary as well. Although estimates of the number of Yugoslavs vary from 45,000 to 105,000 , the actual number probably runs to slightly more than 100,000 . The Croats account for nearly 90 percent of this Yugoslav total, the remainder consisting of nearly equal numbers of Serbs and Slovenes. A small group of Rumanians, estimated variously to number between 15,000 and 25,000, also live in eastern Hungary.

The Jewish community now is estimated to be 80,000 , less than one-quarter of its prewar size. More than 65 percent of the Jews are concentrated in Budapest?

RUMANIA

\begin{tabular}{|l|l|l|}
\hline \multicolumn{3}{|c|}{$\begin{array}{c}\text { Population of Rumania, by Nationality } \\
\text { (1956 Census) }\end{array}$} \\
\hline Rumanians & \multicolumn{1}{|c|}{ Thousand } & \multicolumn{1}{c|}{ Percent of total } \\
\hline Minorities & 14,996 & 85.7 \\
\hline Hungarians & 2,493 & 14.3 \\
\hline Germans & 1,588 & 9.1 \\
\hline Jews & 385 & 2.2 \\
\hline Gypsies & 146 & 0.8 \\
\hline Ukrainians & 104 & 0.6 \\
\hline Yugoslavs & 60 & 0.3 \\
\hline Great Russians & 47 & 0.2 \\
\hline Slovaks & 39 & 0.2 \\
\hline Tatars & 23 & 0.1 \\
\hline Turks & 20 & 0.1 \\
\hline Bulgarians & 14 & negl \\
\hline Czechs & 12 & negl \\
\hline Greeks & 12 & negl \\
\hline Poles & 11 & negl \\
\hline Armenians & 8 & negl \\
\hline Others, including undeclared & 6 & negl \\
\hline Total & 18 & 0.1 \\
\hline & $\mathbf{1 7 , 4 8 9}$ & $\mathbf{1 0 0 . 0}$ \\
\hline
\end{tabular}

The present minority population of Rumania is only about half that of the prewar period, but it is still the largest of any country in Eastern Europe. The drastic reduction in the size of the minority population came about during the World War II period when death, territorial losses (Bessarabia, Northern Bukovina, and Southern Dobruja), and transfers of population combined to greatly reduce the size of nearly every one of the prewar minorities. In the 1930 census 17 separate national minorities, totaling over 5 million people, were recognized; 9 of them had more than 100,000 members each. By the time of the latest census (1956), 15 minorities, totaling under 2.5 million people, were identified; and only 4 of them had more than 100,000 members. Of the major prewar mi-

\footnotetext{
7 Excerpt from National Minorities in Eastern Europe. For a broader picture of Hungary's history and politics see: Hankiss Elemér. Hongrie Diagnostiques: Essai en pathologie sociale. Geneve, 1990; Bibó István. Misère des petits Etats d'Europe de l'Est, L'Harmattan: Paris, 1986; Molnár Miklós. Histoire de la Hongrie, Hatier: Paris, 1996.
} 
norities, only the Hungarians were able to maintain their absolute and relative strength into the postwar period.

By far the largest part of Rumania's postwar minority population (87.5 percent in 1956) is concentrated in Transylvania. Within this region the various minorities account for nearly one-third of the population, and in some sections non-Rumanians may be in the majority. In the historic provinces of Moldavia and Walachia, however, minorities comprise only 2 or 3 percent of the population, and over wide areas non-Rumanians may be entirely absent. Somewhat larger proportions, 10 to 13 percent, are found in Dobruja and Southern Bukovina.

Hungarians: The Hungarian minority in Rumania numbers over 1.5 million and is by far the largest single minority group in Eastern Europe. Nearly all (98 percent) of the Hungarians are settled in Transylvania, where they account for one-quarter of the population, a proportion that has remained essentially the same over a period of several decades.

The Hungarians in Transylvania are concentrated in two areas of settlement that are separated by a zone in which Hungarians are more widely dispersed among the dominant Rumanian population. About 675,000 Szeklers live in a part of eastern Transylvania. They form the largest and most distinctive Hungarian group in Rumania as well as the largest bloc of Hungarians outside Hungary. The second area of major Hungarian concentration is in the western part of Transylvania along the border with Hungary. About 600,000 Hungarians live in this narrow border zone. The relative strength of the Hungarian population, however, is much less in the western border area than in the more compactly settled Szekler area.

Germans: The Germans still comprise the second largest national minority in Rumania, and like the Hungarians, they are concentrated almost entirely in Transylvania, where they comprise about 6 percent of the population. Also like the Hungarians, the Germans are divided into two major groups, with distinctive characteristics.

The Saxon group has been established in the historic province of Transylvania since the 12th century. As compared with nearly 250,000 Saxons in prewar times, the present group numbers about 180,000, some 80 percent of which lives in the southern part of Transylvania. A smaller group is in northern Transylvania.

The Swabians of the Banat area form the second major German group. They now number about 175,000 , or about the same as the Saxons, although in prewar times the Swabian group was larger than the Saxon group. Most of the Swabians live in a comparatively narrow border strip adjoining the Yugoslav Vojvodina and southeastern Hungary.

It is possible that the Rumanian Government eventually may permit large-scale emigration of the German community to West Germany. Such emigration could produce, according to West German estimates, a decrease of 25 percent or more in the size of the German minority. The Rumanians actually have allowed small-scale emigration throughout much of the postwar period, but this has not been enough to affect significantly the overall size of the German minority.

Jews: The actual number of Jews in Rumania today is uncertain, although it is much smaller than it was before the war. The 1956 census listed according to nationality a total Jewish population of only 146,000, but this figure is generally regarded as a serious understatement of the true size of the Jewish community. Estimates from Jewish and other sources for the same period range between 200,000 and 250,000. Estimates of the present Jewish population are further complicated by the more or less steady, and frequently 
heavy, Jewish emigration in recent years. As many as 90,000 to 100,000 Jews may have emigrated since mid-1958. An estimate for early 1964 gave a total of from 120,000 to 150,000 Jews remaining in Rumania, which on the basis of earlier estimates would seem to be approximately correct.

The Jewish population in Rumania is located mainly in urban areas (95 percent) and is unevenly distributed. The largest single concentration $-44,000$, or nearly one-third of the Jews in the country - is in the city of Bucharest. Other important areas of Jewish settlement are in northern Moldavia, particularly in Iaşi, and in central and western Transylvania.

Gypsies: The Gypsy population, numbering more than 100,000, is considerably smaller than it was in the prewar period. Two-thirds of the Gypsies are concentrated in Transylvania, and a relatively large number are in the present Banat Region. The rest of the Gypsies are widely distributed throughout Rumania.

Other Minorities: For the most part the other minority groups in Rumania are essentially small remnants of much larger prewar populations that lived mainly in the territories that were lost by Rumania to the USSR and Bulgaria at the end of the war. Most of these small minority groups are found in the polyglot Dobruja (Turks, Tatars, Great Russians, and a few Ukrainians) and Banat (Yugoslavs, Slovaks, Czechs, and Bulgarians) Regions. Most of the Ukrainians are found along the USSR border in northern Transylvania and Southern Bukovina. The Greek minority is located chiefly in urban centers: Bucharest; the port cities of Brăila, Galaţi, and Constanţa; and the Transylvanian cities of Hunedoara and Oradea. The Poles also are widely distributed, but nearly half of them are in northern Moldavia. The Armenians, who comprise the smallest of the identifiable minority groups in Rumania, have been permitted to emigrate to Lebanon on a more or less regular basis since about 1963. If this movement is allowed to continue it could lead to the virtual elimination of the Armenian minority ${ }^{8}$.

\section{BULGARIA}

Bulgaria is the only country in Eastern Europe in which the relative size of the minority population (about 13 or 14 percent of the total) has remained substantially unchanged since the prewar period. In absolute numbers the minority population actually has increased, from little more than 800,000 at the time of the 1934 census to over 1.1 million at the time of the 1956 census. A large part of this increase, however, is more apparent than real inasmuch as the 1956 census includes nearly 190,000 Macedonians, a group not even identified in the prewar census.

Although the 1956 census identifies 16 separate minority groups, only 3 of them the Turkish, Gypsy, and Macedonian - account for over 94 percent of the total minority population. The Pomak group, which is differentiated on the basis of religion rather than nationality and is not officially recognized, also constitutes a fairly large minority. The other national minorities are extremely small, most of them numbering less than 10,000 and nearly all of them having decreased in size since the war.

\footnotetext{
8 Excerpt from National Minorities in Eastern Europe. For a broader picture of Romania's history and politics see: Ionescu Ghiță. Communism in Rumania, 1944-62. London, 1964; Deletant Dennis. Communist terror in Rumania: Gheorghiu-Dej and the Police State, 1948-1965. London, 1998; Brucan Silviu. The Wasted Generation: Memoirs of the Romanian Journey from Capitalism to Socialism and Back. Boulder, 1993; Georgescu Vlad. The Romanians: A History. Columbus, 1991.
} 


\begin{tabular}{|l|l|l|}
\hline \multicolumn{3}{|c|}{$\begin{array}{c}\text { Population of Bulgaria, by Nationality } \\
\text { (1956 Census) }\end{array}$} \\
\hline Thlgarians & \multicolumn{1}{|c|}{ Thousand } & Percent of total \\
\hline Minorities & $6,506.5$ & 85.5 \\
\hline Turks & $1,107.2$ & 14.5 \\
\hline Gypsies & 656.0 & 8.6 \\
\hline Macedonians & 197.9 & 2.6 \\
\hline Armenians & 187.8 & 2.5 \\
\hline Russians & 22.0 & 0.3 \\
\hline Greeks & 10.6 & 0.1 \\
\hline Jews & 7.4 & 0.1 \\
\hline Tatars & 6.0 & negl \\
\hline Rumanians & 6.0 & negl \\
\hline Karakachni & 3.7 & negl \\
\hline Czechs & 2.1 & negl \\
\hline Albanians & 1.2 & negl \\
\hline Germans & 1.1 & negl \\
\hline Hungarians & 0.7 & negl \\
\hline Kutzo-Vlachs & 0.7 & negl \\
\hline Serbs & 0.5 & negl \\
\hline Others & 0.5 & negl \\
\hline Total & 3.0 & negl \\
\hline & $\mathbf{7 , 6 1 3 . 7}$ & $\mathbf{1 0 0 . 0}$ \\
\hline
\end{tabular}

Turks: As in the past, the Turks form by far the largest national minority in Bulgaria. Although the actual number of Turks exceeds that given in the 1934 census, the relative size of the group has decreased slightly as a result of the large-scale transfers of Turks to Turkey during the last half of the 1930's and again in the postwar period, chiefly between 1948 and 1951. Probably some 250,000 Turks were repatriated, but this loss to Bulgaria was offset in part by an estimated 65,000 Turks who became part of the Turkish minority when Southern Dobruja was transferred from Rumania to Bulgaria in 1940.

Although the 656,000 Turks in Bulgaria may be found in nearly all parts of the country, about 50 percent of them are settled in the northeast, where they comprise about 20 percent of the population; and about 30 percent live in the eastern part of the Rhodope Mountains in the south, where in some places they comprise about 75 percent of the population.

Gypsies: The nearly 200,000 Gypsies comprise the second largest minority and, in contrast to the other large minorities, are distributed over nearly all parts of the country.

Macedonians: The Macedonians are the most highly localized of the important minority groups identified in the census of 1956, at which time fully 90 percent were located in the extreme southwestern part of the country, mainly in the valley of the Struma River and the Pirin Mountains. They comprise nearly two-thirds of the population of the area.

From the Bulgarian point of view the Macedonians form a geographical rather than an ethnical minority in that they speak a language that is basically a dialect of Bulgarian. In prewar times the Bulgarian census did not recognize the existence of a Macedonian mi- 
nority, counting these people as Bulgarians. The present Bulgarian position is in opposition to the position held in Yugoslavia, where the Macedonians are recognized as a separate national group speaking a distinctive South Slav language.

Pomaks (not indicated on map). Although not officially recognized as a national minority in the censuses or in other Bulgarian publications, a fairly large number of Bulgarians known as Pomaks form a cohesive group. They adhere to the Moslem religion, though they retain many customs of Orthodox Bulgarians and speak the Bulgarian language. The unity of the Pomak group is enhanced by its concentration and relative isolation in the rugged country of the western and central Rhodope Mountains. Most of the estimated 130,000 to 140,000 Pomaks live here.

Other Minorities: The smaller minorities in Bulgaria are of little significance. Only the Armenians number more than 20,000, and it is probable that this group will eventually be reduced to only a small fraction of its original size'.

YUGOSLAVIA

\begin{tabular}{|c|l|l|}
\hline \multicolumn{2}{|c|}{$\begin{array}{c}\text { Population of Yugoslavia, by Nationality } \\
\text { (1961 Census) }\end{array}$} \\
\hline Yugoslavs & \multicolumn{1}{|c|}{ Thousand } & Percent of total \\
\hline Serbs & 16,539 & 89.2 \\
\hline Croats & 7,806 & 42.1 \\
\hline Slovenes & 4,294 & 23.1 \\
\hline Macedonians & 1,589 & 8.6 \\
\hline Montenegrins & 1,046 & 5.6 \\
\hline Other Yugoslavs & 514 & 2.0 \\
\hline Minorities & 1,290 & 7.0 \\
\hline Albanians & 2,011 & 10.8 \\
\hline Hungarians & 915 & 4.9 \\
\hline Turks & 504 & 2.7 \\
\hline Slovaks & 183 & 1.0 \\
\hline Bulgarians & 86 & 0.5 \\
\hline Rumanians & 63 & 0.3 \\
\hline Czechs & 61 & 0.3 \\
\hline Italians & 30 & 0.2 \\
\hline Others & 26 & 0.1 \\
\hline \multicolumn{1}{|c|}{ Total } & 143 & 0.8 \\
\hline & $\mathbf{1 8 , 5 4 9}$ & $\mathbf{1 0 0 . 0}$ \\
\hline
\end{tabular}

Ethnically, Yugoslavia is the most complex and heterogeneous country in Eastern Europe. Much of its diversity stems from the fact that Yugoslavia is a multinational state of six republics based on the union of five distinct South Slav nationalities, a situation that is further complicated by the existence of at least 15 national minorities. Efforts to weld it into a more effective unit have been opposed by the competing interests of the several Yugoslav groups, and the existence of important minorities along international borders

\footnotetext{
${ }^{9}$ Excerpt from National Minorities in Eastern Europe. For a broader picture of Bulgaria's history and politics see: Markov Gheorghi. The Truth that Killed, London, 1983; Brown J.F. Bulgaria under Communist Rule. London, 1972.
} 
has embittered relations between Yugoslavia and all its neighbours at one time or another.

The Yugoslav Nationalities. The several Yugoslav nationalities now account for nearly 90 percent of the entire population of the country, a proportion that has grown steadily since the first census in 1921, when they comprised only about 83 percent. The five distinct nationality groups - Serbs, Croats, Slovenes, Macedonians, and Montenegrins - are distinguished on the basis of a number of criteria: language, religion, culture, historical association, and geographical location. Five of the six Yugoslav republics are based on the five Yugoslav nationalities. The sixth, Bosnia-Hercegovina, includes both Croats and Serbs as well as a large number of Moslems and other Yugoslavs of unspecified nationality. Ethnically, the Moslem Yugoslavs are Serbs or Croats who have refused to identify themselves with either of their own groups, mainly on religious grounds. Historically, the Moslem Yugoslavs have remained apart from the Roman Catholic Croats and the Orthodox Serbs. Probably most of the Yugoslavs of unspecified nationality are Serbs or Croats, and many of them may be Moslems.

The Serbs, with more than 40 percent of the total population of the country, and the Croats, with nearly 25 percent, are the two dominant Yugoslav groups. All other Yugoslav nationalities are much smaller, none having as much as 10 percent of the total population. The relative size of the groups, moreover, has not been significantly altered over the past 4 decades, although the Serbs, Macedonians, and Montenegrins have gained slightly at the expense of the more Westernized and economically advanced Croats and Slovenes.

Geographically, each Yugoslav nationality tends to be concentrated in one of the constituent republics, though there are notable variations. Over 95 percent of the Slovenes and Macedonians are settled within their respective republics, whereas only about 75 percent of the Serbs, Croats, and Montenegrins are in theirs.

National Minorities. Although maintaining nearly the same absolute size of about 2 million over the past 40 years, the relative size of Yugoslavia's minority population has decreased noticeably during the same period, from a high of 17 percent of the total population in 1921 to less than 11 percent in 1961. Geographically, the national minorities are concentrated largely in border regions in the northern and southern parts of the country. According to the 1961 census, about 66 percent of the minority population lived in Vojvodina and Kosmet Autonomous Provinces of Serbia, as compared with less than 60 percent at the time of the 1953 census. This increase is due largely to the striking growth in the minority population of Kosmet. About 17 percent of the minority population lives in Macedonia, where it accounts for about 25 percent of the population. The remaining 17 percent is found mainly in Serbia proper (not including Kosmet and Vojvodina) and Croatia, leaving Slovenia, Montenegro, and Bosnia-Hercegovina with only very small proportions of minority peoples.

Albanians: The Albanians constitute the largest and potentially one of the most troublesome minorities in Yugoslavia. The 915,000 Albanians recorded in the 1961 census account for 45 percent of the entire minority population of the country, and their high rate of growth promises to increase this proportion even more in the future. The Albanian minority, doubling in size between 1921 and 1961, has grown much more rapidly than any other large minority group or than any of the Yugoslav nationalities. Between 1953 and 1961, the Albanian group increased by more than 20 percent as compared with only about 10 percent for the population as a whole. A part of this apparent substantial growth probably is due to the tendency to understate the size of the Albanian population 
in 1953; but even with this factor taken into consideration, the growth of the Albanian minority is still as great or greater than that of any other nationality.

About 70 percent of the Albanian minority is concentrated in Kosmet, where it comprises nearly 67 percent of the population of the province. Other, though less homogeneous, areas of Albanian settlement extend beyond the borders of Kosmet into northern and western Macedonia and, to a much smaller extent, also into adjoining sections of Serbia proper and Montenegro. More than 180,000 Albanians live in Macedonia, where they comprise 13 percent of the population, a slightly smaller proportion than in 1953.

Hungarians: The Hungarians, numbering over half a million, are the second largest minority in Yugoslavia, accounting for about 25 percent of the entire minority population. Unlike the Albanian group, however, the number of Hungarians has increased so slowly that their relative importance has declined steadily over the past 4 decades. Nearly 88 percent of the Hungarians live in Vojvodina in the extreme northern part of Serbia, and most of the remaining 12 percent live in adjoining districts in eastern Croatia.

Within Vojvodina the Hungarians do not dominate to the same extent that the Albanians do in Kosmet. The 442,000 Hungarians comprise only about 25 percent of the population of Vojvodina, although they comprise 70 percent of the minority population of the province. The heaviest concentration of Hungarians is in the northern part, chiefly between the Danube and Tisa Rivers, but they are also scattered throughout most other parts of Vojvodina.

Turks: The Turks probably number about 180,000, but the reporting on the size of the Turkish minority is one of the most unreliable features of Yugoslav censuses. Great variations in the count occur from one census to the next, often as a result of changing political conditions. It is likely that in 1948 many Turks reported themselves as of Albanian nationality, whereas by 1953 relations between Yugoslavia and Albania had deteriorated so seriously that two and one-half times as many people $(260,000)$ claimed Turkish nationality. The number of people claiming Turkish as their mother tongue in 195.3, however, was only 182,000. That this latter figure may represent more accurately the true size of the Turkish minority in Yugoslavia is borne out in some degree by the 1961 census, which recorded 183,000 people claiming Turkish nationality.

Like the Albanian and Hungarian minorities, the Turkish minority exhibits a high degree of geographic concentration. In 1953, 84 percent of the Turks (by mother tongue) lived in Macedonia. Although the percentage has decreased to some extent, the 1961 census recorded nearly 73 percent of the Turks (by nationality) in this province. Most of the remaining Turkish population is in Kosmet and in Serbia proper, the latter region in particular showing a marked increase in the size of its Turkish minority.

Other Minorities: The other minority groups in Yugoslavia are comparatively small and, for the most part, do not constitute serious problems in either internal or external relations. The Germans, who prior to World War II comprised the second largest minority, now arc reduced to a group no more than 10 percent of its former size. The 1953 census counted about 60,000 Germans, most of whom were settled in Vojvodina and parts of Croatia. The results of the 1961 census so far made available fail to identify a German minority. About 85 percent of the Slovaks are concentrated in Vojvodina, particularly in the southern half. Much smaller concentrations of Slovaks, along with most of the Czechs are in the north-central Croatia. The small Bulgarian minority is concentrated in three districts of southeastern Serbia bordering Bulgaria. Two of these districts, which were acquired from Bulgaria after World War I, are over 90 percent Bulgarian, giving them the 
highest proportion of minority population of any section of the country. The Ukrainians, most of whom live in three districts of Vojvodina and in one district of BosniaHercegovina, form one of the most widely distributed of the smaller minorities. The Great Russian and Polish minorities also are small and widely scattered.

The Rumanian minority is localized in the southeastern part of Vojvodina, whereas the related Vlach population is centred in the Timok area of northeastern Serbia. The actual size of the Vlach population is not known accurately, however, and at times the Vlachs have been counted as Rumanians. A considerable part of the Vlach population probably has been assimilated into the dominant Serbian group. The 1953 census lists only 35,000 persons claiming Vlach nationality, although 210,000 gave Vlach as their mother tongue. The results of the 1961 census so far published do not even identify a Vlach group. The small Italian minority, settled chiefly in southern Istria, decreased about 30 percent between 1953 and 1961. Nearly half of the small Greek minority is concentrated in Macedonia, and most of the rest is scattered widely across Serbia.

A sizable, though somewhat indeterminate, Gypsy population is widely distributed throughout much of Serbia and Macedonia but is largely absent in the other republics. The 1953 census recorded about 85,000 persons claiming Gypsy nationality, but the actual number probably is much higher as many Gypsies are believed to have declared themselves to be Serbs or Macedonians. The prewar Jewish minority of some 70,000 to 80,000 now probably numbers no more than 6,000 . These people are found chiefly in urban centers such as Zagreb, Belgrade, and Sarajevo, each of which has 1,000 or more Jews ${ }^{10}$.

ALBANIA

\begin{tabular}{|c|l|l|}
\hline \multicolumn{3}{|c|}{$\begin{array}{c}\text { Population of Albania, by Nationality } \\
\text { (Estimate, about 1961) }\end{array}$} \\
\hline \multicolumn{1}{|c|}{ Thousand } & \multicolumn{1}{|c|}{ Percent of total } \\
\hline Albanians & 1,580 & 95.2 \\
\hline Minorities & 80 & 4.8 \\
\hline Greeks & 40 & 2.4 \\
\hline Yugoslavs & 15 & 0.9 \\
\hline Vlachs & 10 & 0.6 \\
\hline Gypsies & 10 & 0.6 \\
\hline Others & 5 & 0.3 \\
\hline Total & $\mathbf{1 , 6 6 0}$ & $\mathbf{1 0 0 . 0}$ \\
\hline
\end{tabular}

It is almost impossible to ascertain precisely the size and distribution of minorities in Albania, although it is undoubtedly true that the relative importance of minorities in the total population has declined substantially since the prewar period. According to most sources the absolute size of the minority population has remained essentially the same

\footnotetext{
10 Excerpt from National Minorities in Eastern Europe. For a broader picture of Yugoslavia's history and politics see: Djilas Milovan. Rise and Fall. New York, 1985; Dennison Rusinow, The Yugoslav Experiment, 1948-1974, Berkeley, 1977; Francine Friedman, The Bosnian Muslims: Denial of a Nation, Boulder, 1996; Steven L. Burg, Paul S. Shoup, The War in Bosnia-Herzegovina: Ethnic Conflict and International Intervention, New York, 1999; Ante Cuvalo, The Croatian National Movement, 1966-1972, New York, 1990; Laura Silber, Allan Little, The Death of Yugoslavia, London, 1995; Misha Glenny, The Fall of Yugoslavia, London, 1992; Stefano Bianchini, Problema iugoslavă, Bucureşti, 2003.
} 
since about 1930, running to approximately 80,000. In 1930 minorities comprised some 8 or 9 percent of the total population, whereas by 1961 they accounted for less than 5 percent.

The Greek minority is the largest and most troublesome, but estimates of its size have varied greatly. At present it probably numbers about 40,000. Much uncertainty exists concerning the size of the minority comprised of various Yugoslav nationalities. The 1955 census (the latest official data available) counted fewer than 6,000 Yugoslavs, somewhat more than were indicated in prewar estimates. A Russian estimate for 1961, however, gives a total of 15,000 - a number that far exceeds all earlier estimates. Although the 1955 census does not identify the Vlach and Gypsy groups, these two peoples have long been part of the population of Albania and postwar estimates give 10,000 for each group $^{11}$.

\section{CONCLUSIONS}

The realities and the policies adopted by the Communist authorities of these states no longer surprise anyone now, approximately three decades after the collapse of Communism in Eastern Europe, but in the Communist Bloc such a document or objective analysis on the issue of minorities would have attracted a severe punishment upon it's author or upon anyone found having it in his possession, a punishment that could have gone as far as loss of life or many years in a forced labor camp during the periods when the system intensified the repression of its own citizens.

\begin{tabular}{|c|c|c|c|c|}
\hline \multicolumn{5}{|c|}{ Estimated Size of National Minority Population in Eastern Europe, by Country ${ }^{12}$} \\
\hline & \multicolumn{2}{|c|}{$\begin{array}{l}\text { Prewar Population within } \\
\text { Prewar Boundaries }\end{array}$} & \multicolumn{2}{|c|}{$\begin{array}{c}\text { Postwar Population within } \\
\text { Postwar Boundaries }\end{array}$} \\
\hline & Thousand & $\begin{array}{c}\text { Percent of } \\
\text { Country To- } \\
\text { tal }\end{array}$ & Thousand & $\begin{array}{c}\text { Percent of } \\
\text { Country Total }\end{array}$ \\
\hline Poland & 10,295 & 32.3 & 1,450 & 4.8 \\
\hline Czechoslovakia & 5,060 & 34.4 & 1,010 & 7.4 \\
\hline Hungary & 1,120 & 12.9 & $440-740$ & 4.4-7.4 \\
\hline Rumania & 5,075 & 28.1 & 2,493 & 14.3 \\
\hline Bulgaria & 805 & 13.2 & 1,107 & 14.5 \\
\hline Yugoslavia & 2,070 & 17.1 & 2,010 & 10.8 \\
\hline Albania & 75 & 8.2 & 80 & 4.8 \\
\hline Total & 24,500 & 26.0 & $8,590-8,890$ & 8.7-9.0 \\
\hline
\end{tabular}

Some conclusions can be drawn quickly. First of all, the professionalism of the briefing's author(s) is worth mentioning. A concise and analytical text, well structured and balanced, which gives the reader a clear and realistic picture of the issue of national minorities in Eastern Europe in the early 1960s, but also a historical perspective on the evo-

11 Excerpt from National Minorities in Eastern Europe. For a broader picture of Albania's history and politics see: Prifti P.R. Socialist Albania since 1944: Domestic and Foreign Development. Cambridge, 1978; The Artful Albanian: The Memoirs of Enver Hoxha, ed. Jon Halliday. London, 1986; Griffith William E. Albania and the Sino-Soviet Rift. Cambridge, 1963; Arshi Pipa, Albanian Stalinism: Ideo-political Aspects, Boulder, 1990; Biberaj Elez. Albania: A Socialist Maverick. Boulder, 1990.

12 Apud National Minorities in Eastern Europe. 
lution of various ethnic groups compared to the interwar period. The document is also an example of critical analysis, because it takes the official statistical data provided by the Communist authorities, especially the data of official censuses, and interprets them in a logical and realistic way.

Secondly, only by comparing the share that national minorities had in Eastern Europe after about two decades of Communism with the interwar period can we see the extent of ethnic cleansing or assimilation policies that accompanied border changes during and immediately after World War II; policies that were still active in the early 1960s in the form of pressure or encouragement to emigrate in the case of certain ethnic groups (see the case of Germans, Jews, etc.).

\begin{tabular}{|l|l|l|}
\hline \multicolumn{3}{|c|}{ Estimated Size of Principal Minority Groups in Eastern Europe ${ }^{13}$} \\
\hline & $\begin{array}{c}\text { Prewar Population } \\
\text { within Prewar Bounda- } \\
\text { ries }\end{array}$ & $\begin{array}{c}\text { Postwar Population } \\
\text { within Postwar } \\
\text { Boundaries }\end{array}$ \\
\cline { 2 - 3 } Thousand & \multicolumn{1}{|c|}{ Thousand } \\
\hline Germans & 5,790 & $800-2,000$ \\
\hline Ukrainians & 5,630 & 330 \\
\hline Jews & 4,740 & 300 \\
\hline Hungarians & 2,610 & 2,630 \\
\hline Belorussians & 1,700 & 170 \\
\hline Turks/Tatars & 1,030 & 880 \\
\hline Great Russians & 600 & 80 \\
\hline Albanians & 510 & 920 \\
\hline Gypsies & 460 & 750 \\
\hline Bulgarians & 370 & 80 \\
\hline Czechs/Slovaks & 330 & 250 \\
\hline
\end{tabular}

Not least, the document notes the destructive potential of rivalries between dominant groups within multinational states, such as the case of Czechoslovakia and Yugoslavia, anticipating the peaceful or violent outcome of their post-Communist dissolution.

It was declassified and made available to the public on April 19th 2001.

Beauvois, D. (1995). Histoire de la Pologne. Paris.

\section{REFERENCES}

Bianchini, S. (2003). Problema iugoslavă [The Yugoslav problem]. Bucarest.

Biberaj, E. (1990). Albania: A Socialist Maverick. Boulder.

Bibó, I. (1986). Misère des petits Etats d'Europe de l'Est. L'Harmattan: Paris.

Bogdan, H. (1982). De Varsovie à Sofia. Histoire des pays de l'Est. Paris.

Brown, J.F. (1972). Bulgaria under Communist Rule. London.

Brucan, S. (1993). The Wasted Generation: Memoirs of the Romanian Journey from Capitalism to Socialism and Back. Boulder.

Burg, S.L. \& Shoup, P.S. (1999). The War in Bosnia-Herzegovina: Ethnic Conflict and International Intervention. New York.

Cuvalo, A. (1990). The Croatian National Movement, 1966-1972. New York.

Deletant, D. (1998). Communist terror in Rumania: Gheorghiu-Dej and the Police State, 1948-1965. London.

13 Apud National Minorities in Eastern Europe. 
Djilas, M. (1985). Rise and Fall. New York.

Dubcek, A. (1993). C'est l'espoir qui meurt en dernier. Fayard: Paris.

Friedman, F. (1996). The Bosnian Muslims: Denial of a Nation. Boulder.

Georgescu, V. (1991). The Romanians: A History. Columbus.

Glenny, M. (1992). The Fall of Yugoslavia. London.

Griffith, W.E. (1963). Albania and the Sino-Soviet Rift. Cambridge.

Halliday, J. (Ed.) (1986). The Artful Albanian: The Memoirs of Enver Hoxha. London.

Hankiss, E. (1990). Hongrie Diagnostiques: Essai en pathologie sociale. Geneve.

Havel, V. (1989-1990). Essais politiques. Points / Calman-Levy: Paris.

Ionescu, G. (1964). Communism in Rumania, 1944-62. London.

Lipták, L. (1996). Petite histoire de la Slovaquie. Institut d'études slaves: Paris.

Marès, A. (1994). Histoire des Pays techèques et slovaque. Hatier: Paris.

Markov, G. (1983). The Truth that Killed. London.

Molnár, M. (1996). Histoire de la Hongrie. Hatier: Paris.

Pipa, A. (1990). Albanian Stalinism: Ideo-political Aspects. Boulder.

Prifti, P.R. (1978). Socialist Albania since 1944: Domestic and Foreign Development. Cambridge.

Rusinow, D. (1977). The Yugoslav Experiment, 1948-1974. Berkeley.

Silber, L. \& Little, A. (1995). The Death of Yugoslavia. London.

Soulet, J.F. (1998). Istoria comparată a statelor comuniste din 1945 până în zilele noastre. [Comparative history of Communist states from 1945 to the present day]. Bucarest [in Romanian].

Tymowski, M. (1993). Une histoire de la Pologne (Essais et documents). Paris.

\section{Артур Тулуш}

(Галацький університет «Нижній Дунай», Галац, Румунія)

e-mail: arthur.tulus@ugal.ro

ORCID: https://orcid.org/0000-0002-4368-7231

\section{Стан національних меншин у Східній Європі в секретному звіті ЦРУ за 1965 рік}

У контексті холодної війни детальне знання противника та шпигунство були фундаментальними елементами політики безпеки двох протиборчих сторін. ЦРУ, служба зовнішньої розвідки США, визначило становище етнічних меншин як одну з можливих вразливих сторін «Східного табору», судячи з точки зору обмежувальної політики комуністичних держав щодо їх прав і свобод. Наше дослідження засноване на аналізі документа, підготовленого ЦРУ у 1965 р., меморандуму, в якому були використані дані останніх офіційних переписів населення Болгарії, Румунії, Югославії, Албанії, Чехословаччини, Угорщини та Польщі, а також зафіксовано вплив політики асиміляції. Аналітики зосереджені на національних меншинах у східних комуністичних державах. Документ тим цікавіший, що питання про права національних меншин у комуністичному світі було табуйоване.

У першу чергу, варто відзначити професіоналізм авторів меморандуму. Короткий та аналітичний текст, добре структурований і збалансований, дає читачеві чітке та реалістичне уявлення про проблему національних меншин ц Східній Європі на початку 1960х років, а також історичну перспективу еволюції різних етнічних груп ц порівнянні 3 періодом між двома світовими війнами. Цей документ також $є$ прикладом критичного аналізу, оскільки він бере офіційні статистичні дані, надані комуністичною владою, особливо дані офіційних переписів, та інтерпретує їх логічно і реалістично.

По-друге, тільки порівнюючи долю національних меншин у Східній Європі протягом двох десятиліть комунізму з міжвоєнним періодом, ми можемо побачити масштаби політики етнічних чисток або асиміляції, що супроводжувала зміни кордонів під час і відразу після Другої світової війни. Дана політика все ще була активна на початку 1960-х років у формі тиску або заохочення до еміграції по відношенню до певних етнічних груп (німці, євреї і т.д.).

Не в останню чергу в документі наголошується деструктивний потенціал суперниц- 
тва між домінуючими групами всередині багатонаціональних держав, як, наприклад, у випадку Чехословаччини та Югославії, які очікували мирного або насильницького результату їх посткомуністичного розпаду.

Ключові слова: Східна Європа, холодна війна, комуністичні режими, демографічна статистика, питання меншин 